\title{
Mycobacterium leprae Hsp65 administration reduces the lifespan of aged high antibody producer mice
}

\author{
Estevam José Baldon ${ }^{1}$, Eliana Blini Marengo ${ }^{2}$, Marcelo de Franco ${ }^{3}$, Nancy Starobinas ${ }^{3}$, Valquiria Bueno ${ }^{4^{*}}$ \\ and Osvaldo Augusto Sant'Anna'
}

\begin{abstract}
Background: Aging process may result in immune modifications that lead to disruption of innate and acquired immunity mechanisms that may induce chronic-degenerative events. The heat shock proteins (Hsp), phylogeneticaly conserved among organisms, present as main function the ability of folding and refolding proteins, but they also are associated with chronic-degenerative disorders. Here were evaluated the role of M. leprae native Hsp65 (WT) and its point-mutated $\left(\mathrm{K}^{409} \mathrm{~A}\right)$ on survival and anti-DNA and anti-Hsp65 antibody production of aged genetically selected mice for high $\left(H_{\| I}\right)$ and low $\left(L_{\| I}\right)$ antibody production; data from 120- and 270-days old mice (named "adult" or "aged", respectively) were compared.
\end{abstract}

Results: WT Hsp65 administration induces reduction in the mean survival time of adult and aged female $\mathrm{H}_{\| I}$ mice, this effect being stronger in aged individuals. Surprisingly, the native protein administration increased the survival of aged female $L_{\| \mid}$when compared to $\mathrm{K}^{409} \mathrm{~A}$ and control groups. No survival differences were observed in aged male mice after Hsp65 proteins inoculation. We observed increase in IgG1 anti-Hsp65 in $\mathrm{WT}$ and $\mathrm{K}^{409} \mathrm{~A}$ aged $\mathrm{H}_{\text {III }}$ female mice groups and no marked changes in the anti-DNA (adult and aged $\mathrm{H}_{\| 1}$ ) and anti-Hsp65 lgG1 or lgG2a isotypes production in adult $\mathrm{H}_{\| \mid}$female and aged male mice. $\mathrm{L}_{\| \mid}$male mice presented increased anti-DNA and anti-Hsp65 IgG2a isotype production after $\mathrm{WT}$ or $\mathrm{K}^{409} \mathrm{~A}$ injection, and $\mathrm{L}_{\text {|II }}$ female groups showed no alterations.

Conclusions: The results revealed that the WT Hsp65 interferes with survival of aged $\mathrm{H}_{\text {III }}$ female mice without involvement of a remarkable IgG1 and IgG2a anti-DNA and anti-Hsp65 antibodies production. The deleterious effects of Hsp65 on survival time in aged $\mathrm{H}_{\| \mid}$female mice could be linked to a gender-effect and are in agreement with those previously reported in lupus-prone mice.

Keywords: Heat shock protein, Hsp65, Aging, Immunosenescence, Antibody response

\section{Background}

Aging is defined as progressive alterations of biological functions, leading to the onset of diseases and reduced ability to respond to external stimuli [1]. Alongside with the physiological aging events, the immunosenescence accumulates potential modifications in immunological functions and its components. The most important changes include the decrease of the absolute number of lymphocytes, alterations of the activation status of $\mathrm{T}$ cells,

\footnotetext{
*Correspondence: vbueno@unifesp.br

${ }^{4}$ Departamento de Microbiologia, Imunologia e Parasitologia, UNIFESP, Rua Botucatu 862, 04023-062 São Paulo, Brasil

Full list of author information is available at the end of the article
}

increasing of serum levels of immunoglobulin (mainly IgA and IgG), limitation of the protective response of specific high affinity antibody, amplification of autoantibody production and a switch for a Th2 pattern of cytokine response [2]. The altered processes in advanced age also result in the failure of self and non-self discrimination [3] and disruption of the innate and acquired immunity mechanisms, which may result in chronic-degenerative events and subsequent loss of life quality [4-7]. Altogether, these modifications lead to an increased vulnerability to infections [8,9], reduced response to vaccines [10], development of tumors $[11,12]$, and autoimmune or inflammatory diseases $[13,14]$. In addition, disorders related to the 
abnormal processing, modification, and aggregation of proteins typically linked to biological properties of the heat shock proteins (Hsp) are reported [15,16].

Drastic alterations in physiological responses to stressful events are related to Hsp production [17-19]. Hsp are phylogeneticaly conserved molecules among evolutionary scale $[20,21]$ which assist misfolding molecules and control the arising of toxic protein aggregates, supporting the folding and unfolding of polypeptides for degradation by proteolytic machinery [22,23]. Hsp65, the most abundant and immunogenic protein of mycobacteria [24], is considered a toxin and dominant antigen in infectious diseases, capable of induce humoral and cellular immune responses [25-27]. Reports evidenced the immunodominant role of the Hsp60 family in infectious processes [28], besides of the role played in inflammatory processes such as arthritis, type I diabetes, multiple sclerosis and atherosclerosis [29-32]. In the opposite, some studies demonstrate its regulatory function on immune suppression in rheumatoid arthritis [33] and type I diabetes [34].

Previously, our group evaluated the immunomodulatory effects in vivo of M. leprae Hsp65 on genetically homogeneous $(\mathrm{NZBxNZW}) \mathrm{F}_{1}$ hybrid female mice that develop systemic lupus erythematosus (SLE); the results showed that the native protein (WT) aggravates the lupus progression in mice [35]. On the other hand, the $\mathrm{K}^{409} \mathrm{~A}$, a pointmutated Hsp65 [36], revealed a potential in mitigating lupus aggravation in these mice [37]. Hsp65 administration also increased eye lesions in mice susceptible to the development of autoimmune uveitis [38].

Autoimmune diseases are more frequent in aged and in female individuals [39] and thus we asked whether Hsp65 interference in autoimmunity is age and/or gender-related. Reports of Hsp65 interference in autoimmunity and other biological alterations occurring during the immunosenescence process are related to gender and aging [40]. These findings lead us to investigate whether M. leprae Hsp65 is also involved in alterations of aged individuals, as the immunosenescence process can lead to the onset of autoimmunity. It was assessed the role played by passive administrations of WT and mutant $\mathrm{K}^{409} \mathrm{~A}$ Hsp65 on the lifespan and antibody production of aged $\mathrm{H}_{\mathrm{III}}$ and $\mathrm{L}_{\mathrm{III}}$ mice. We conclude that the WT protein administration interferes with the survival of aged and adults $\mathrm{H}_{\mathrm{III}}$ female mice, even though the anti-DNA and anti-Hsp65 antibody production was not markedly changed. As no significant changes in male mice survival and antibodies production were observed we conclude that Hsp65 effects were gender-related.

\section{Results}

\section{WT Hsp65 administration reduces the lifespan of $\mathrm{H}_{\mathrm{III}}$} female mice

Male and female two hundred-seventy-days old (aged) mice were inoculated intraperitonially with a single dose of $2.5 \mu \mathrm{g}$ /animal of WT or $\mathrm{K}^{409} \mathrm{~A}$ Hsp65 in $0.2 \mathrm{~mL}$ of PBS, or only PBS as control group. Mice were observed until death for mean survival time (MST) and environmental variance $\left(\mathrm{V}_{\mathrm{E}}\right)$ determination (Table 1). Figure 1A illustrates the survival reduction of aged $\mathrm{H}_{\mathrm{III}}$ female mice inoculated with the native protein (308 \pm 25 days, $p<$ 0.01 ) compared to controls ( $530 \pm 123$ days). Also it was observed a decrease of 24-fold in the WT group phenotypic variance $\left(\mathrm{V}_{\mathrm{E}}=635\right.$ days in WT group versus $\mathrm{V}_{\mathrm{E}}=$ 15293 days in control group). Conversely, Figure 1B shows that aged $\mathrm{L}_{\text {III }}$ females inoculated with WT Hsp65 presented higher MST $(615 \pm 46$ days; $p<0.01)$ compared to $\mathrm{K}^{409} \mathrm{~A}$ (442 \pm 97 days) and control group (441 \pm 72 days) and a decrease in $\mathrm{V}_{\mathrm{E}}$ (2180 days) in contrast with control (5328 days) and $\mathrm{K}^{409} \mathrm{~A}$ (9590 days) groups. No survival differences were observed in aged male mice from both $\mathrm{H}_{\mathrm{III}}$ and $\mathrm{L}_{\mathrm{III}}$ in all experimental groups (Figure $1 \mathrm{C}$ and D).

Since the lifespan of aged $\mathrm{H}_{\mathrm{III}}$ females (270-days old) was shortened after WT Hsp65 inoculation, we asked whether the same effect could be observed in adult $\mathrm{H}_{\text {III }}$ female mice (120-days old) injected with Hsp65 (Figure 2). Adult $\mathrm{H}_{\mathrm{III}}$ female mice showed a MST reduction after WT protein administration ( $466 \pm 134$ days; $p<0.01)$ when compared to $\mathrm{K}^{409} \mathrm{~A}$ injected group ( $665 \pm 37$ days). The first death occurred 247 days after inoculation of the native molecule, and the environmental variance was lower in mutant- (1422 days, 22-fold less) and WT-inoculated animals (18181 days, about 2-fold less) compared to control group (31473 days).

It is noteworthy that in mice from both lines and ages no weight loss, piloerection or ascites were detected.

\section{Anti-DNA and anti-Hsp65 antibody production are altered after WT Hsp65 injection}

Since the antibody production against heat shock proteins are involved in autoimmune processes, we measured the anti-DNA and anti-Hsp65 IgG1 and IgG2a isotypes production after WT and point-mutated Hsp65 inoculation. In aged $\mathrm{H}_{\mathrm{III}}$ female mice, WT and $\mathrm{K}^{409} \mathrm{~A}$ inoculation caused a 4.5-fold increase in anti-Hsp65 IgG1 production $(p<0.01)$ (Figure 3A), compared to pre-immune animals (zero days), at fourteen and seven days post-inoculation, respectively. Despite the reduction observed in IgG2a anti-Hsp65 (Figure 3A) and IgG1 anti-DNA (Figure 3B) observed in aged $\mathrm{H}_{\text {III }}$ female mice, the non-inoculated group (control) also showed this decrease, possibly indicating an environmental interference non-related with the protein injection. No differences in IgG2a anti-DNA production were observed.

Antibody production kinetics analysis of aged $\mathrm{H}_{\mathrm{III}}$ female mice shows an increase of the IgG1 anti-Hsp65 ( $p<$ 0.01 ) in the WT-injected group, starting at $2.8 \log _{2}$ and reaching $5.4 \log _{2}$ on day fourteen, and $3.3 \log _{2}$ to $6 \log _{2}$ in 
Table 1 Mean survival time (days) and environmental variance of $H_{\text {III }}$ and $L_{\text {III }}$ mice

\begin{tabular}{|c|c|c|c|c|c|c|}
\hline & & ㅇ $\mathrm{H}_{\mathrm{III}}$ adult & o $\mathrm{H}_{\mathrm{III}}$ aged & ㅇ $\mathrm{L}_{\text {III }}$ aged & $\partial^{\lambda} \mathrm{H}_{\mathrm{III}}$ aged & $\delta^{\lambda} L_{\text {III }}$ aged \\
\hline \multirow[t]{3}{*}{ Control } & MST & $614 \pm 177$ & $531 \pm 123$ & $442 \pm 72$ & $469 \pm 84$ & $575 \pm 97$ \\
\hline & $V_{E}$ & 31473 & 15294 & 5329 & 7141 & 9534 \\
\hline & & $(n=4)$ & $(n=6)$ & $(n=5)$ & $(n=6)$ & $(n=7)$ \\
\hline \multirow[t]{3}{*}{ WT } & MST & $466 \pm 134^{*}$ & $308 \pm 25^{* *}$ & $615 \pm 46^{* *}$ & $403 \pm 88$ & $463 \pm 141$ \\
\hline & $V_{E}$ & 18182 & 635 & 2180 & 7802 & 20018 \\
\hline & & $(n=4)$ & $(n=6)$ & $(n=5)$ & $(n=8)$ & $(n=8)$ \\
\hline \multirow[t]{3}{*}{$\mathrm{K}^{409} \mathrm{~A}$} & MST & $665 \pm 37$ & $492 \pm 61$ & $442 \pm 97$ & $537 \pm 151$ & $496 \pm 134$ \\
\hline & $V_{E}$ & 1422 & 3823 & 9591 & 23097 & 18093 \\
\hline & & $(n=4)$ & $(n=5)$ & $(n=5)$ & $(n=7)$ & $(n=8)$ \\
\hline
\end{tabular}

Mean survival time (MST) and environmental variance $\left(\mathrm{V}_{\mathrm{E}}\right)$ are shown for control, WT (native Hsp65) and $\mathrm{K}^{409} \mathrm{~A}$ (mutant $\mathrm{K}^{409} \mathrm{~A} \mathrm{Hsp65)}$ injected mice groups, males $\left({ }^{\lambda}\right)$ and females (). The values are displayed as plus/minus standard deviation. The number of subject used for each treatment is indicated in parenthesis. ${ }^{*} p<0.05$ and ${ }^{* *} p<0.01$ related to the control of each mice group.

$\mathrm{K}^{409} \mathrm{~A}$ group $(p<0.05)$ on $7^{\text {th }}$ day post-immunization when compared to pre-immune serum (data not shown).

In adult $\mathrm{H}_{\mathrm{III}}$ female mice, the administration of both WT and $\mathrm{K}^{409} \mathrm{~A}$ Hsp65 molecules did not promote alterations in the anti-Hsp65 antibody production kinetics between all experimental groups until 33 days postinoculation (Figure 4A). However, the anti-DNA titer was increased at $33^{\text {rd }}$ days in WT $(p<0.01)$ and $\mathrm{K}^{409} \mathrm{~A}$
( $p<0.05$ ) groups (Figure 4B). Regarding aged $\mathrm{H}_{\text {III }}$ male mice, the isotypes titration showed only increased IgG1 anti-Hsp65 isotype production compared to pre-immune groups at the $14^{\text {th }}$ day after the $\mathrm{K}^{409} \mathrm{~A}$ Hsp65 injection (data not shown).

After the observation of the increased survival of aged $\mathrm{L}_{\mathrm{III}}$ female mice injected with WT Hsp65, we investigated the effects of those molecules over the

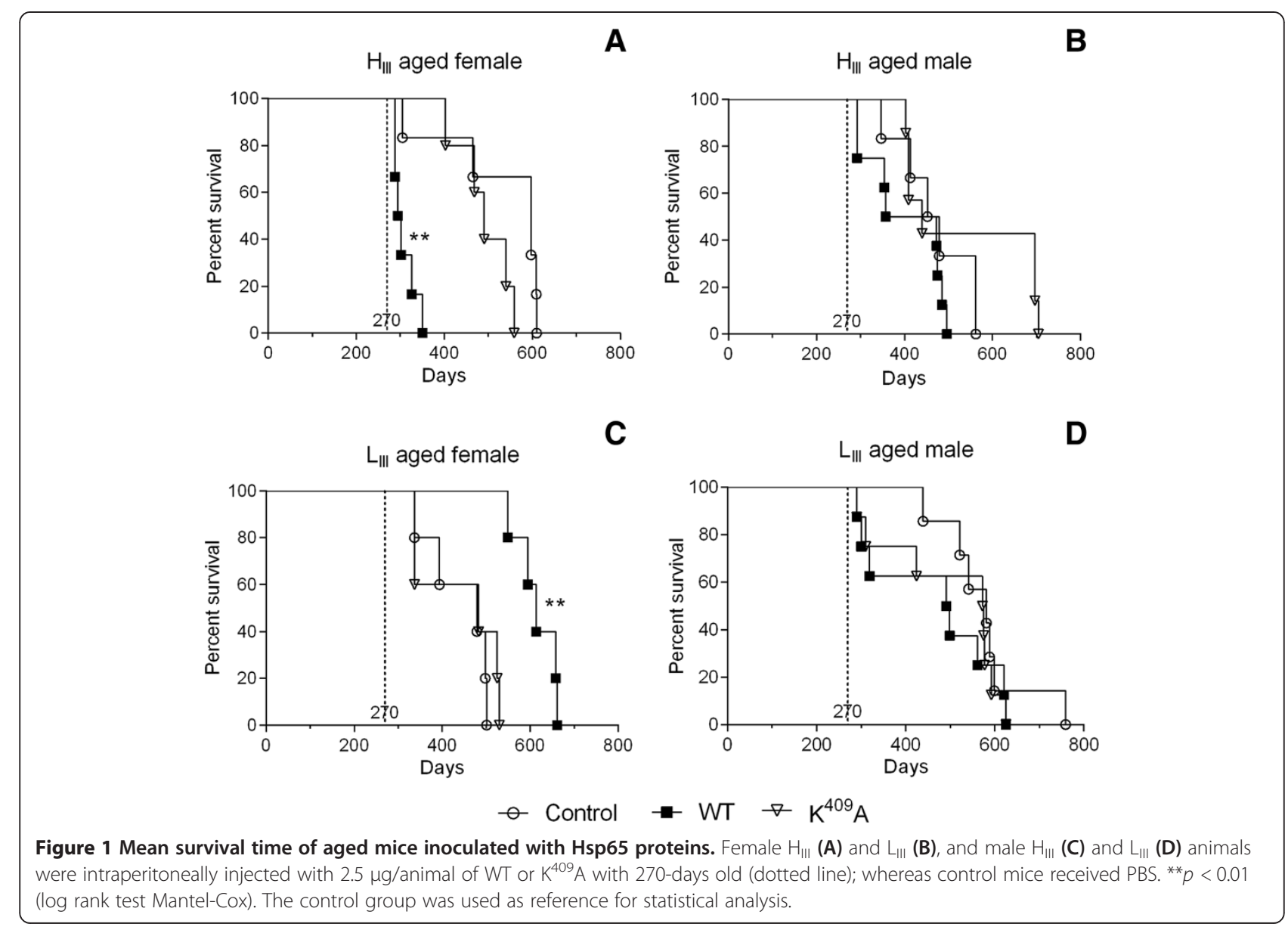




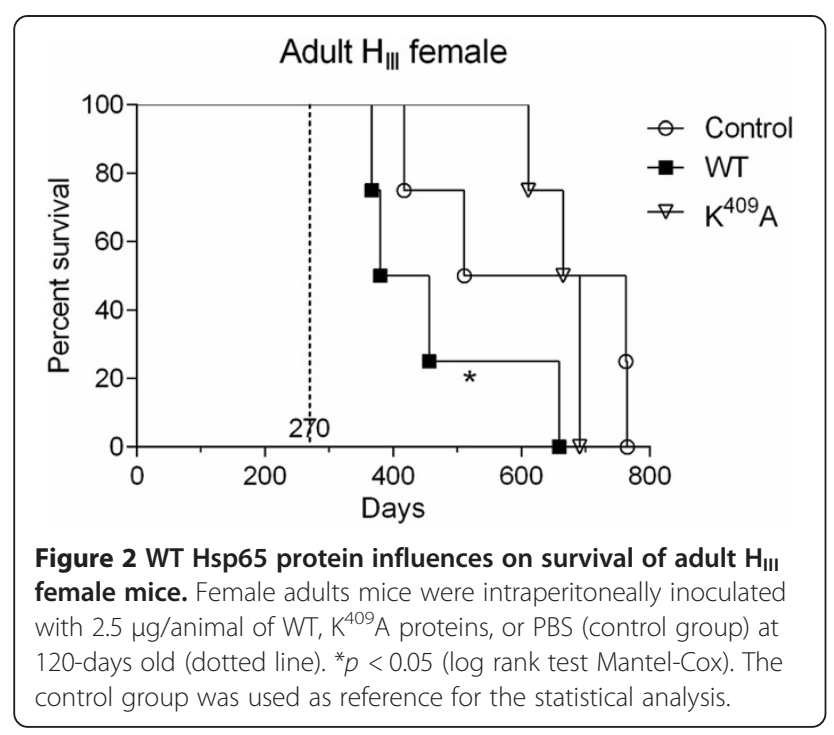

antibody production in low antibody responder mice. No differences were observed in IgG1 (titers range from $3.7 \pm 0.8$ to $4.2 \pm 0.5 \log _{2}$ ) and IgG2a (from $5.5 \pm$ 0.8 to $7.0 \pm 1.0 \log _{2}$ ) anti-Hsp65 or IgG1 (from $2.0 \pm 0.4$ $\log _{2}$ to $2.5 \pm 0.8 \log _{2}$ ) and IgG2a (from $2.4 \pm 0.5 \log _{2}$ to
$4.0 \pm 1.9 \log _{2}$ ) anti-DNA production in aged $\mathrm{L}_{\mathrm{III}}$ female mice after WT or $\mathrm{K}^{409} \mathrm{~A}$ Hsp65 inoculation (Figure 5A and $\mathrm{B})$. On the other hand, $\mathrm{L}_{\mathrm{III}}$ male mice showed elevated levels of IgG2a anti-Hsp65 after 14 days subsequently the WT $(p<0.001)$ or $\mathrm{K}^{409} \mathrm{~A}(p<0.05)$ injection (Figure $5 \mathrm{C}$ ), whereas the anti-DNA data displayed mainly an increase in IgG2a anti-Hsp65 after WT $(p<0.001)$ and $\mathrm{K}^{409} \mathrm{~A}(p<0.01)$ inoculation (Figure 5D).

\section{Discussion}

Immunological functions may change with aging and lead to a deficient immune response to several infections and vaccines, predisposing the individual to chronicdegenerative processes by the decline of self-tolerance maintenance and loss of tissue integrity, directing to crypt antigens release, amplified bystander activation and molecular mimicry events $[2,41,42]$. Based on the immune alterations observed in the aging process, the reports of higher incidence of chronic-degenerative processes in elders $[14,43]$ and the deleterious effect of $M$. leprae Hsp65 administration on murine lupus and autoimmune uveitis $[35,38]$, we evaluated the interference of WT Hsp65 administration on survival time and correlation with antibody production in $\mathrm{H}_{\mathrm{III}}$ and $\mathrm{L}_{\mathrm{III}}$ mice. The animals from
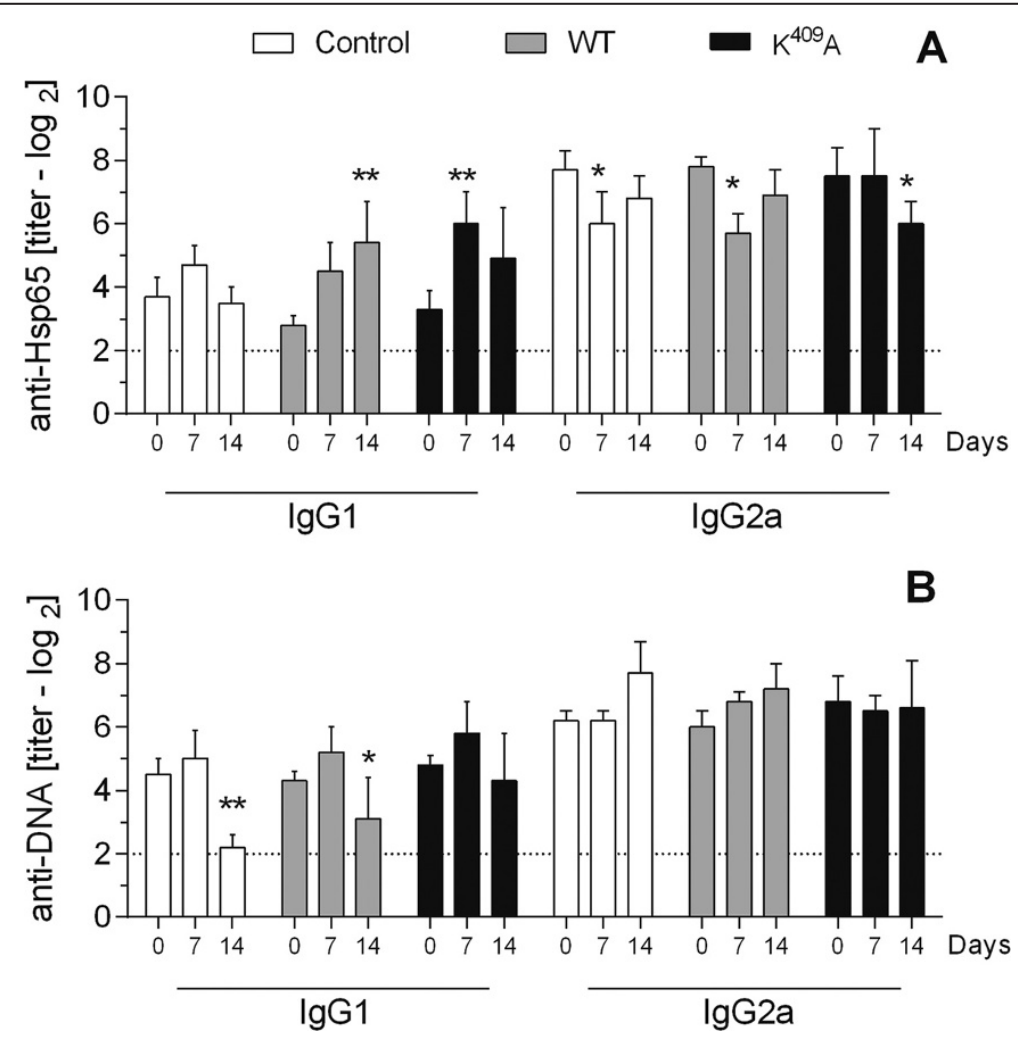

Figure 3 Anti-Hsp65 and anti-DNA antibodies production in aged $\mathbf{H}_{\text {III }}$ female mice. Anti-Hsp65 IgG1 and lgG2a (A), and anti-DNA lgG1 and lgG2a (B) isotype production in the serum of aged mice (3-6 animals/group) inoculated with WT, $\mathrm{K}^{409} \mathrm{~A}$ Hsp65, or PBS (control). Antibody titers were set by ELISA before (day 0 ) and after 7 and 14 days post Hsp65 inoculation. ${ }^{*} p<0.05$ and ${ }^{* *} p<0.01$ (Two-way ANOVA, Bonferroni multiple comparisons post-test). 

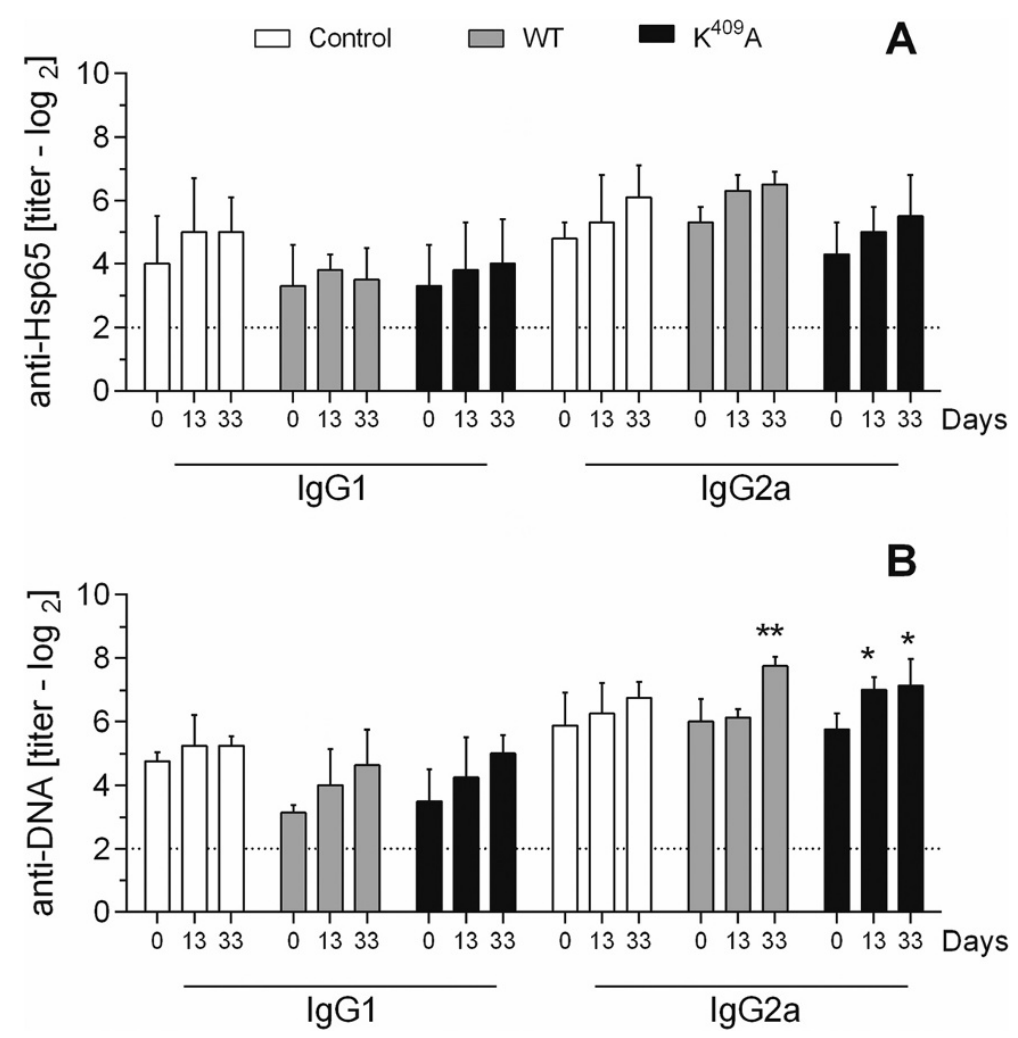

Figure 4 Anti-Hsp65 and anti-DNA antibodies production in adult $\mathbf{H}_{\text {III }}$ female mice. Anti-Hsp65 IgG1 and IgG2a (A), and anti-DNA IgG1 and IgG2a (B) isotype production in the serum of adult $\mathrm{H}_{\text {III }}$ female mice (4 animals/group) inoculated with WT, $\mathrm{K}^{409} \mathrm{~A}$ Hsp65, or PBS (control). Antibody titers were determined by ELISA before (day 0 ) and after 13 and 33 days post Hsp65 inoculation. ${ }^{*} p<0.05$ and ${ }^{* *} p<0.01$ (Two-way ANOVA, Bonferroni multiple comparisons post-test).

Selection III are a well-established model to understand the humoral immune response and its influences over the susceptibility to infections [44], autoimmunity [45] and tumorigenesis [46]; they also differ in the response to antigens not related to those used for the selection procedure [47] and present different susceptibility to autoimmune disease [48]. Moreover, $\mathrm{H}_{\mathrm{III}}$ and $\mathrm{L}_{\mathrm{III}}$ mice are used to verify the influence of genetic alterations over longevity, as demonstrated by the differences between the survival of distinct genetic bidirectional selections: Selection I and II presents different survival between lines and gender and Selection III shows similar mean survival time regardless of sex or linage $\left(\mathrm{H}_{\mathrm{III}}: 611 \pm 153\right.$ days, $\mathrm{L}_{\mathrm{III}}: 622 \pm 166$ days $)$ $[49,50]$.

Native Hsp65 effects on survival of aged and adults $\mathrm{H}_{\text {III }}$ female mice indicate the immunological interference of the Hsp65 molecule in this model. It reduced the survival of $\mathrm{H}_{\mathrm{III}}$ female mice, mainly in young aged (270-days old), with first death occurring 18 days after WT administration, whereas for adults $\mathrm{H}_{\text {III }}$ female mice (120-days old) it occurred 247 days post-injection, a period 14-times greater than the aged mice. In opposition, WT-inoculated aged $\mathrm{L}_{\mathrm{III}}$ female mice presented higher MST (615 \pm 46 days, $p<$ $0.01)$ compared to mutant and control groups (442 \pm 97 and $441 \pm 72$ days, respectively). Despite the differences of the maximal survival time in control groups (Additional file 1), we can take these data in account as the maximal survival obtained was within to those previously observed [50], with 501 days in aged $\mathrm{L}_{\mathrm{III}}$ female and 759 days in aged $\mathrm{L}_{\text {III }}$ male mice. The maximal survival of control group of $\mathrm{H}_{\mathrm{III}}$ female (763 and 765 days) or $\mathrm{L}_{\mathrm{III}}$ male (759 days) showed a significant difference because some mice died with extreme lifespan. Despite the low number of animals used (restricted by the ethics committee) the results demonstrated that the M. leprae Hsp65 injection could alter the survival, reducing MST in $\mathrm{H}_{\mathrm{III}}$ and augmenting in $\mathrm{L}_{\mathrm{III}}$ female mice.

Considering that $\mathrm{L}_{\mathrm{III}}$ line shows an 18-fold reduction in the antibody production and low T cell proliferation [51], it is possible to consider that the humoral response of $\mathrm{L}_{\mathrm{III}}$ mice against Hsp65 is reduced, resulting in an easy management by the system to return to homeostasis. The same could be true for other mice lines with lower antibody response compared to $\mathrm{H}_{\mathrm{III}}$ mice, like Swiss albino mice (foundation of Selection III lines) [47]. Contrary, the high responder rate of the immunological system in $\mathrm{H}_{\mathrm{III}}$ female mice after WT injection, despite the antibody production rate, could disrupt the homeostasis and lead to a 




reduced survival. Homeostasis imbalance due to aging process in association with the interference of Hsp65 inoculation could explain the higher decrease in survival of $\mathrm{H}_{\mathrm{III}}$ aged female. In spite of our animal model do not spontaneously develop autoimmune processes, the reduced survival time of $\mathrm{H}_{\mathrm{III}}$ female mice matches to the experiments involving lupus-prone mice [35] and models of experimental autoimmune uveitis in mice [38], and reassure the involvement of Hsp in chronic-degenerative processes. The control expression and the rupture of Hsp65 balance in SLE development were ascertained through the approach of inductive disequilibrium of physiological and immune states by homologous Hsp [52] and the same could be true for the current study.

Since High and Low mice lines differ, respectively, to high or low antibody responses, the anti-DNA and antiHsp65 IgG isotypes production were analyzed after WT or $\mathrm{K}^{409} \mathrm{~A}$ Hsp65 inoculation. $\mathrm{H}_{\mathrm{III}}$ and $\mathrm{L}_{\mathrm{III}}$ mice, both genders, presented slightly higher production of IgG2a anti-Hsp65 and anti-DNA related to the IgG1 isotype. This balance towards a Th1 response may indicate a natural pro-inflammatory status in these strains which is confirmed by the relative easy way to induce adjuvant arthritis in $\mathrm{H}_{\text {III }}$ mice [53]. The time-course analyses of immunoglobulin production did not show significant intragroup differences, which might be related to the absence of a strong specific response to these proteins demonstrated by the low antibody titers even 30 days after the protein inoculation and because this is not an immunization process. Compared to pre-immune mice, aged $\mathrm{H}_{\mathrm{III}}$ females presented an increase of anti-Hsp65 IgG1 in the group treated with WT or $\mathrm{K}^{409} \mathrm{~A}$ Hsp65 and a non-related reduction of IgG2a. In murines, the IgG1 and IgG2a functions are dependent on the cells activation threshold determined by the affinity of antibodies and the expression of inhibitors/activators receptors [54]. The amplification of anti-Hsp65 IgG1 antibody (approximately 4-times) should be related with a switch to a Th2 response, previously observed in the immunosenescence process [2]. It also could correlate to the precocious death of aged $\mathrm{H}_{\text {III }}$ female mice, since the augment of Th2 cytokines, despite its regulatory effect, are involved in some diseases like asthma, allergies and autoimmunities $[55,56]$.

Confirmed the M. leprae Hsp65 effect on reduced survival in aged $\mathrm{H}_{\mathrm{III}}$ female mice, it was evaluated whether the anti-DNA and anti-Hsp65 antibody production were agedependent by comparing the IgG isotypes with adults $\mathrm{H}_{\mathrm{III}}$ female mice. They did not present intergroup changes in kinetics of anti-DNA or anti-Hsp65 antibodies production, 
but adult $\mathrm{H}_{\mathrm{III}}$ female mice showed increase in IgG2a titers after Hsp65 molecules injection. The IgG2a isotype titers are remarkably lower in adult mice compared to aged ones as an indicative of a better balance of Th1/Th2 response and maintaining homeostasis of the immune system, as demonstrated by the 13-times later death in adult $\mathrm{H}_{\mathrm{III}}$ females after WT inoculation compared to old mice.

This dominating effect observed in the survival time of aged mice emphasizes the involvement of the Hsp65 molecule in aging processes. The effect of native molecule was gender-specific, as demonstrated by the unaltered MST in aged male mice $\left(\mathrm{H}_{\mathrm{III}}\right.$ and $\left.\mathrm{L}_{\mathrm{III}}\right)$ inoculated with both proteins, and potentially related with the differential regulation of the immunological system by sexual hormones [57], as the dimorphism between gender is positively linked with different susceptibility for infections, autoimmune diseases and tumor incidence $[40,58]$. Sexual hormones (mostly estrogen but also progesterone and testosterone) affect immune cells quantitatively and qualitatively and impact on cytokine production [59]. Females have higher plasma concentrations of immunoglobulin, increased number and strong activation of $\mathrm{CD}_{4}^{+} \mathrm{T}$ cells, elevated levels of Th1 cytokines (IgG2a production) and stronger primary and secondary antibody response [60,61]. Indeed, the higher incidence of SLE in females reflects the gender dimorphism $[62,63]$.

It should also be considered the animal model used to test the relationship of Hsp and aging. The opposite phenotypes of antibody production in $\mathrm{H}_{\mathrm{III}}$ and $\mathrm{L}_{\mathrm{III}}$ mice include immune response to a wide range of antigens [47]. The $\mathrm{F}_{0}$ - foundation population - of Selection III mice are genetically heterogeneous: the phenotypic variance $\left(V_{P}\right)$ is due to the sum of the genetic variance $\left(\mathrm{V}_{\mathrm{G}}\right)$, and the environmental variance $\left(\mathrm{V}_{\mathrm{E}}\right)$ emerges by all the causes of variability resulting from the environment. The bi-directional selection resulted in a progressive increase $\left(\mathrm{H}_{\text {III }}\right.$ mice) or a decrease $\left(\mathrm{L}_{\mathrm{III}}\right.$ mice) in mean antibody response, followed by the decline of $\mathrm{V}_{\mathrm{G}}$ in both lines $[47,64]$. Therefore, the alterations provoked by WT or $\mathrm{K}^{409} \mathrm{~A} H \mathrm{Hsp} 65$ administration (the environmental feature applied during the experiments) provide the variance in our experimental model. After WT inoculation, a great reduction in variance value was observed in aged female $\mathrm{H}_{\mathrm{III}}\left(\mathrm{V}_{\mathrm{E}}=635\right.$ versus $\mathrm{V}_{\mathrm{E}}=$ 15293 of the control group) than $\mathrm{L}_{\mathrm{III}}$ mice $\left(\mathrm{V}_{\mathrm{E}}=2180\right.$ versus $\mathrm{V}_{\mathrm{E}}$ controls $\left.=5328\right)$, showing the impact of this molecule administration over the potential of death phenotype $\left(\mathrm{MST}=308 \pm 25\right.$ in aged $\mathrm{H}_{\mathrm{III}}$ and MST = $615 \pm 46$ in aged $\mathrm{L}_{\mathrm{III}}$ female mice). We cannot exclude the interference of others genetic factors occurred during the selective breeding, and a gender-effect that may affect the response in $\mathrm{H}_{\mathrm{III}}$ and $\mathrm{L}_{\mathrm{III}}$ mice. Since it was proposed that the presence of anti-Hsp60 autoantibodies, innate risk factor of atherosclerosis in adulthood, may be an inherited trait, we are conducting studies about the effect of Hsp65 in $\left(\mathrm{H}_{\mathrm{III}} \mathrm{xL}_{\mathrm{III}}\right) \mathrm{F}_{1}$ hybrids to clarify the genetic influence of this susceptibility [65].

Mechanisms underlying the distinct effects of the native Hsp65 on survival of $\mathrm{H}_{\mathrm{III}}$ and $\mathrm{L}_{\mathrm{III}}$ mice, and the comparison between them and mutant injected individuals are under evaluation. Preliminary histopathological analysis with some control- and WT-injected $\mathrm{H}_{\mathrm{III}}$ female mice (3 animals/ group) indicates that the WT Hsp65 inoculation results in a widespread chronic hepatitis, spleen hyperplasia, and, unlike $\mathrm{L}_{\mathrm{III}}$ female, higher degree of nephrosis and chronic nephritis with inflammatory infiltration of plasma cells, macrophages and lymphocytes (data not shown), characteristics also present in human lupus nephritis [66]. Studies of immune cells alterations in spleen and blood samples of aged $\mathrm{H}_{\mathrm{III}}$ female mice injected with $M$. leprae $\mathrm{Hsp} 65$ are in progress. The initial results shows increased splenic B cells percentage, amplified expression of CD45RA and CD154 in $\mathrm{CD}^{+}{ }^{+} \mathrm{T}$ cells, reflecting on the augmented anti-Hsp65 IgG1 isotype production observed here, and amplified surface expression of CD11b and CD11c in blood monocytes.

The adaptive management of biological systems according to environmental changes is essential for the organism survival and Hsp molecules can interfere with immune phenotypes submitted to independent polygenic control. The aging process presents an impaired cellular homeostasis and the Hsp presentation by antigen presenting cells may be diminished, being responsible for the decline in immunoregulation through the recognizing of self Hsp [67]. On the other hand, an amplified expression of stress proteins and his antigenic determinants can evolve to a pathogenic or regulation of chronic-degenerative processes [68-70]. Taking together, these facts explain the pleiotropic effects of Hsp65 on biological systems and its wide actions over different cell types and production of other molecules. Based on pleiotropy, the Theory of Aging proposed by George C. Williams suggests that some genes responsible for increased fitness in young fertile individuals may contribute to the reduction of such capacity in later life [71]. Then, it is conceivable that selection for high antibody production genes, essential for the immune protection through the life of an individual, can be one of the factors that allows Hsp65 act on the immune or physiological imbalance later in life. As previously reported by our group, the WT Hsp65 passive administration affects the endogenous balance by increase the entropy of the individual system; the linear equation proposed $(\mathrm{y}=\mathrm{a}+\Delta i)$ shows that the immunological history (y) is unique, irreversible and cumulative [35]. In this study, the animal model employed is not naturally predisposed to autoimmunity, so "a" should include the potential advent of chronic-degenerative processes in aging and " $i$ " consists by the sum of the environmental factors that modulate the entropy: age, gender, antibody production rate, and possible cellular and molecular alterations established in 
Selection III after Hsp65 administration. All these elements interfere in how Hsp65 interact with the immune system; consequently, the greater their influence, greater the entropic energy, hindering the recovery of homeostasis and contributing to the deaths of $\mathrm{H}_{\mathrm{III}}$ female mice.

Despite the absence of strikingly differences in antibody production in our experiments, perhaps the 2-fold higher antibodies production in $\mathrm{H}_{\mathrm{III}}$ females compared to males [47], associated with the senescent immune system and influenced by hormones, are sufficient to induce frailty after WT administration. In parallel, the high antibodies production rate in $\mathrm{H}_{\mathrm{III}}$, besides increasing the system entropy, can result in reduced antibody affinity for the protein, facilitating its subsequent binding to self-antigens. In case of imbalance due to the overstimulation by stress or inflammation, autoimmune diseases may emerge or aggravate $[35,52]$. The opposed occurs in $\mathrm{L}_{\mathrm{III}}$ females, which presented increased survival when injected with the native molecule, suggesting that the low immunoglobulin production may favor the control of immune system overstimulation.

We do not observed any signs of disease development during the survival time assay and this be correlated with the incapacity of the mycobacterial Hsp65 alone to induce, in some cases, autoimmunity. In an experiment of arthritis induction by Complete Freund's adjuvant (CFA) replaced with the whole mycobacterium [72], the intradermal injection induced arthritic lesions at the same degree as CFA in ankle joints, with the production of antiDNA and anti-Hsp65 in rats. Thus, the not remarkable increase of anti-Hsp65 antibodies presented by $\mathrm{H}_{\mathrm{III}}$ and $\mathrm{L}_{\mathrm{III}}$ mice may be responsible for the absence of disease.

More than a phenotypic effect by the antibody production against WT Hsp65, the extended pleiotropic effect of this protein over the immune system results in strengthening of naturally established disorders in aged $\mathrm{H}_{\text {III }}$ female mice who possibly present a natural higher degree of entropy. In addition, the age-remodeled immune system already shows a major entropy level and the injection of M. leprae WT Hsp65 in females reinforce an imbalance that does not resemble the young individuals, originating disorganizations and irreversible processes leading to death.

\section{Conclusions}

Here we verified in an aging mice model the role of $M$. leprae Hsp65 in the aggravation of phenotypes, as observed in SLE and experimental autoimmune uveitis, and outlined its interference mainly in aged $\mathrm{H}_{\mathrm{III}}$ female inducing precocious death. We assume that this effect is associated to the aging process and related to gendereffect instead of the amount of antibody produced in these mice lines. Studies of cellular and cytokines alterations after the Hsp65 administration in Selection III mice and its $\left(\mathrm{H}_{\mathrm{III}} \mathrm{xL}_{\mathrm{III}}\right) \mathrm{F}_{1}$ hybrid mice are in progress to elucidate the mechanisms by which this heat shock protein and its responses act in the immune system of aged individuals.

\section{Methods}

Expression of the recombinants M. leprae Hsp65 in Escherichia coli and purification

Clone pIL161, containing the coding sequence of the $M$. leprae WT Hsp65 and its point-mutated form $\mathrm{K}^{409} \mathrm{~A}$ [36] were amplified in E. coli DH5a cells. Expression and purification of the recombinant Hsp65 WT and $\mathrm{K}^{409} \mathrm{~A}$ was described elsewhere [35].

\section{Animals}

The genetically heterogeneous selected mice for High $\left(\mathrm{H}_{\mathrm{III}}\right)$ or Low $\left(\mathrm{L}_{\mathrm{III}}\right)$ antibody production were bred in the animal facility of the Immunogenetic Laboratory and maintained at the animal facility of the Immunochemistry Laboratory, both in Butantan Institute. They were housed in groups of four to five in plastic cages filled with hardwood bedding, provided with water and rodent chow ad libitum, in a room with 12-h light/dark cycle, controlled pressure, humidity and temperature $\left(24 \pm 2^{\circ} \mathrm{C}\right)$. All procedures are in agreement to the International Animal Welfare Recommendations [73] and the experiments are in conformity with the Ethical Principles in Animal Research, adopted by the Brazilian College of Animal Experimentation, and was approved by the Ethical Committee for Animal Research of Butantan Institute (CEUAIB \#475/08).

\section{Administration of the WT and $\mathrm{K}^{409} \mathrm{~A} \mathrm{Hsp} 65$ molecules}

Male and female $\mathrm{H}_{\mathrm{III}}$ and $\mathrm{L}_{\mathrm{III}}$ mice at the age of 120 - or 270-days old (named here "adult" or "aged" mice, respectively) were inoculated intraperitonially with a single dose of $2.5 \mu \mathrm{g}$ of WT or $\mathrm{K}^{409} \mathrm{~A}$ Hsp65 of M. leprae in $0.2 \mathrm{~mL}$ of phosphate buffer saline $\mathrm{pH} 7.4$ (PBS); as controls, mice were injected with $0.2 \mathrm{~mL}$ PBS. In this study it is important to highlight that the periodically bleedings were performed at different time points in aged and adult female mice; from previously observations that aged $\mathrm{H}_{\text {III }}$ female animals death started 18 days after the WT Hsp65 administration (bleedings occurred at seven and at fourteen days post proteins administration). Differently, adult $\mathrm{H}_{\text {III }}$ female individuals, which presented an extended survival time after the WT Hsp65 inoculation, were bled after fourteen and thirty-three days after the proteins injection; this longer interval was used to avoid external stress stimuli that could influence the experiment. The serum samples were stored at $-20^{\circ} \mathrm{C}$ until antibody titration. Each animal was observed until death for the designing of the longevity curve and examined for clinical signs that include development of ascites and lethargy. 


\section{Titration of anti-DNA and anti-Hsp65 antibodies}

Levels of anti-DNA and anti-Hsp65 IgG1 and IgG2a isotypes titers were set by indirect ELISA as describe before [35] and expressed as $\log _{2}$ of the reciprocal serum dilution giving an absorbance value of $20 \%$ of the saturation level.

\section{Statistical analyses}

All statistical analyses were performed with GraphPad Prism 5.0 software. The antibody dosages are expressed as mean \pm SD. Two-way ANOVA with Bonferroni multiple comparisons post-test were used to evaluate the antibody production between mice from control, WT and $\mathrm{K}^{409} \mathrm{~A}$ groups. Kaplan-Meier plot for mean survival time (MST) was analyzed by log-rank test (Mantel-Cox) comparing the MST with age, dose or administration period of WT or $\mathrm{K}^{409} \mathrm{~A}$ rHsp65. For all data, minimum statistical significance was set at $p<0.05$.

\section{Additional file}

Additional file 1: Percent survival of control groups in Selection III mice. $H_{\| \mid}$and $L_{|| l}$ from control group, used in survival analysis, were compared. The adults (270-days old) and young aged (120-days old) female $H_{\| \mid}$mice where analyzed together. Those mice received PBS $(200 \mu \mathrm{L} /$ animal) at 120- or 270-days as previously described. Statistical analysis (log rank test (Mantel-Cox)): ${ }^{a} p<0.05 \mathrm{H}_{\| \mid}$male versus $\mathrm{H}_{\| \mid}$female; ${ }^{\mathrm{b}} p<0.05 \mathrm{H}_{\| \mid}$male versus $L_{\| \mid}$male; ${ }^{c} p<0.05 \mathrm{H}_{\| \mid}$female versus $L_{\| \mid}$female and ${ }^{d} p<0.01 L_{\| \mid}$female versus $L_{\|||}$male.

\section{Competing interests}

The authors declare that they have no competing interests.

\section{Authors' contributions}

$E J B, E B M, V B$ and OAS participated in the design of the study and writing of the manuscript. EJB performed the assays and analyzed the data. MDF and NS provided the mice used in all experiments and participated in the design of the experiments. VB assisted the discussion of results and writing of the manuscript. All authors read and approved the final manuscript.

\section{Acknowledgements}

This work is supported by the National Institute of Science and Technology in Toxins (INCTTOX), São Paulo Research Foundation (FAPESP) and the National Council of Technological and Scientific Development (CNPq) and Center of Toxins, Immune-Response and Cell Signaling CeTICS - FAPESP 2013/07467-1. EJB and EBM are recipients of an FAPESP fellowship. MDF, NS, VB and OAS are researchers of CNPq-Brazil. The funders had no role in study design, data collection and analysis, decision to publish, or preparation of the manuscript.

\section{Author details}

'Laboratório de Imunoquímica, Instituto Butantan, Avenida Vital Brazil 1500, 05530-900 São Paulo, Brasil. ' Hospital Israelita Albert Einstein, Avenida Albert Einstein, 627/701, 05652-000 São Paul, Brasil. Laboratório de Imunogenética, Instituto Butantan, Avenida Vital Brazil 1500, 05530-900 São Paulo, Brasil. ${ }^{4}$ Departamento de Microbiologia, Imunologia e Parasitologia, UNIFESP, Rua Botucatu 862, 04023-062 São Paulo, Brasil.

Received: 26 November 2013 Accepted: 22 March 2014 Published: 26 March 2014

\section{References}

1. Vo TK, Godard P, de Saint-Hubert M, Morrhaye G, Swine C, Geenen V, Martens HJ, Debacq-Chainiaux F, Toussaint O: Transcriptomic biomarkers of the response of hospitalized geriatric patients with infectious diseases. Immun Ageing 2010, 7:9.
2. Ginaldi L, Loreto MF, Corsi MP, Modesti M, de Martinis M: Immunosenescence and infectious diseases. Microbes Infect 2001, 3:851-857.

3. Prelog M: Aging of the immune system: a risk factor for autoimmunity? Autoimmun Rev 2006, 5:136-139.

4. Cossarizza A, Ortolani C, Monti D, Franceschi C: Cytometric analysis of immunosenescence. Cytometry 1997, 27:297-313.

5. Franceschi C, Bonafe M, Valensin S, Olivieri F, de Luca M, Ottaviani E, de Benedictis $\mathrm{G}$ : Inflamm-aging. An evolutionary perspective on immunosenescence. Ann N Y Acad Sci 2000, 908:244-254.

6. Licastro F, Candore G, Lio D, Porcellini E, Colonna-Romano G, Franceschi C, Caruso $C$ : Innate immunity and inflammation in ageing: a key for understanding age-related diseases. Immun Ageing 2005, 2:8.

7. Hasler $P$, Zouali M: Immune receptor signaling, aging, and autoimmunity. Cell Immunol 2005, 233:102-108.

8. Janssens JP, Krause KH: Pneumonia in the very old. Lancet Infect Dis 2004, 4:112-124.

9. Lynch JP 3rd, Walsh EE: Influenza: evolving strategies in treatment and prevention. Semin Respir Crit Care Med 2007, 28:144-158.

10. Bouree P: Immunity and immunization in elderly. Pathol Biol (Paris) 2003, 51:581-585

11. Zhang $H G$, Grizzle WE: Aging, immunity, and tumor susceptibility. Immunol Allergy Clin North Am 2003, 23:83-102. vi.

12. Trzonkowski P, Mysliwska J, Pawelec G, Mysliwski A: From bench to bedside and back: the SENIEUR Protocol and the efficacy of influenza vaccination in the elderly. Biogerontology 2009, 10:83-94.

13. Johnson SA, Cambier JC: Ageing, autoimmunity and arthritis: senescence of the B cell compartment - implications for humoral immunity. Arthritis Res Ther 2004, 6:131-139.

14. Yung RL, Julius A: Epigenetics, aging, and autoimmunity. Autoimmunity 2008, 41:329-335.

15. Tower J: Hsps and aging. Trends Endocrinol Metab 2009, 20:216-222.

16. Morimoto Rl: Proteotoxic stress and inducible chaperone networks in neurodegenerative disease and aging. Genes Dev 2008, 22:1427-1438.

17. Pockley AG: Heat shock proteins as regulators of the immune response. Lancet 2003, 362:469-476.

18. Srivastava P: Roles of heat-shock proteins in innate and adaptive immunity. Nat Rev Immunol 2002, 2:185-194.

19. Welch WJ: Heat shock proteins functioning as molecular chaperones: their roles in normal and stressed cells. Philos Trans R Soc Lond B Biol Sci 1993, 339:327-333.

20. Lindquist S, Craig EA: The heat-shock proteins. Annu Rev Genet 1988, 22:631-677.

21. Wong HR: Heat shock proteins. Facts, thoughts, and dreams. A. De Maio. Shock 11:1-12, 1999. Shock 1999, 12:323-325.

22. Mayer MP: Gymnastics of molecular chaperones. Mol Cell 2010, 39:321-331.

23. Bukau B, Weissman J, Horwich A: Molecular chaperones and protein quality control. Cell 2006, 125:443-451.

24. Thole JE, Hindersson P, de Bruyn J, Cremers F, van der Zee J, de Cock H, Tommassen J, van Eden W, van Embden JD: Antigenic relatedness of a strongly immunogenic 65 kDA mycobacterial protein antigen with a similarly sized ubiquitous bacterial common antigen. Microb Pathog 1988, 4:71-83.

25. Kong TH, Coates AR, Butcher PD, Hickman CJ, Shinnick TM: Mycobacterium tuberculosis expresses two chaperonin-60 homologs. Proc Natl Acad Sci U S A 1993, 90:2608-2612.

26. Qamra R, Mande SC: Crystal structure of the 65-kilodalton heat shock protein, chaperonin 60.2, of Mycobacterium tuberculosis. J Bacterio/ 2004, 186:8105-8113.

27. Qamra R, Srinivas V, Mande SC: Mycobacterium tuberculosis GroEL homologues unusually exist as lower oligomers and retain the ability to suppress aggregation of substrate proteins. J Mol Biol 2004, 342:605-617.

28. Kaufmann SH: Heat shock proteins and the immune response. Immunol Today 1990, 11:129-136.

29. Bonato VL, Lima VM, Tascon RE, Lowrie DB, Silva CL: Identification and characterization of protective T cells in hsp65 DNA-vaccinated and Mycobacterium tuberculosis-infected mice. Infect Immun 1998, 66:169-175.

30. Wick G, Perschinka $H$, Millonig G: Atherosclerosis as an autoimmune disease: an update. Trends Immunol 2001, 22:665-669.

31. Georgopoulos C, McFarland H: Heat shock proteins in multiple sclerosis and other autoimmune diseases. Immunol Today 1993, 14:373-375.

32. Afek A, George J, Gilburd B, Rauova L, Goldberg I, Kopolovic J, Harats D, Shoenfeld Y: Immunization of low-density lipoprotein receptor deficient 
(LDL-RD) mice with heat shock protein 65 (HSP-65) promotes early atherosclerosis. J Autoimmun 2000, 14:115-121.

33. de Kleer IM, Kamphuis SM, Rijkers GT, Scholtens L, Gordon G, de Jager W, Hafner R, van de Zee R, van Eden W, Kuis W, Prakken BJ: The spontaneous remission of juvenile idiopathic arthritis is characterized by CD30+ $T$ cells directed to human heat-shock protein 60 capable of producing the regulatory cytokine interleukin-10. Arthritis Rheum 2003, 48:2001-2010.

34. Hooper PL, Hooper JJ: Loss of defense against stress: diabetes and heat shock proteins. Diabetes Technol Ther 2005, 7:204-208.

35. Marengo EB, de Moraes LV, Faria M, Fernandes BL, Carvalho LV, Tambourg DV, Rizzo LV, Portaro FC, Camargo AC, Sant'anna OA: Administration of M. leprae Hsp65 interferes with the murine lupus progression. PLOS One 2008, 3:e3025.

36. Portaro FC, Hayashi MA, de Arauz LJ, Palma MS, Assakura MT, Silva CL, de Camargo AC: The Mycobacterium leprae hsp65 displays proteolytic activity. Mutagenesis studies indicate that the M. leprae hsp65 proteolytic activity is catalytically related to the HsIVU protease. Biochemistry 2002, 41:7400-7406.

37. Marengo EB, de Moraes LV, Melo RL, Balan A, Fernandes BL, Tambourgi DV Rizzo LV, Sant'Anna OA: A Mycobacterium leprae Hsp65 mutant as a candidate for mitigating lupus aggravation in mice. PLoS One 2011, 6:e24093.

38. Marengo EB, Commodaro AG, Peron JP, de Moraes LV, Portaro FC, Belfort $\mathrm{R}$ $J$ r, Rizzo LV, Sant'Anna OA: Administration of Mycobacterium leprae rHsp65 aggravates experimental autoimmune uveitis in mice. PLoS One 2009, 4:e7912

39. Pan Z, Chang C: Gender and the regulation of longevity: implications for autoimmunity. Autoimmun Rev 2012, 11:A393-A403.

40. Ottonello L, Frumento G, Arduino N, Bertolotto M, Mancini M, Sottofattori E, Dallegri F, Cutolo M: Delayed neutrophil apoptosis induced by synovial fluid in rheumatoid arthritis: role of cytokines, estrogens, and adenosine. Ann N Y Acad Sci 2002, 966:226-231.

41. Olson JK, Croxford JL, Miller SD: Virus-induced autoimmunity: potential role of viruses in initiation, perpetuation, and progression of T-cellmediated autoimmune disease. Viral Immunol 2001, 14:227-250.

42. McElhaney JE, Effros RB: Immunosenescence: what does it mean to health outcomes in older adults? Curr Opin Immunol 2009, 21:418-424.

43. Dorshkind $\mathrm{K}$, Montecino-Rodriguez E, Signer RA: The ageing immune system: is it ever too old to become young again? Nat Rev Immunol 2009, 9:57-62.

44. Mouton D, Stiffel C, Biozzi G: Genetic factors of immunity against infection. Ann Inst Pasteur Immunol 1985, 136D:131-141.

45. de Franco M, Gille-Perramant MF, Mevel JC, Couderc J: T helper subset involvement in two high antibody responder lines of mice (Biozzi mice): HI (susceptible) and HII (resistant) to collagen-induced arthritis. Eur J Immunol 1995, 25:132-136.

46. Ibanez OM, Mouton D, Ribeiro OG, Bouthillier Y, de Franco M, Cabrera WH, Siqueira M, Biozzi G: Low antibody responsiveness is found to be associated with resistance to chemical skin tumorigenesis in several lines of Biozzi mice. Cancer Lett 1999, 136:153-158.

47. Biozzi G, Mouton D, Sant'Anna OA, Passos HC, Gennari M, Reis MH, Ferreira VC, Heumann AM, Bouthillier Y, Ibanez OM, Stiffel C, Siqueira M: Genetics of immunoresponsiveness to natural antigens in the mouse. Curr Top Microbiol Immunol 1979, 85:31-98.

48. Thompson SJ, Rook GA, Brealey RJ, van der Zee R, Elson CJ: Autoimmune reactions to heat-shock proteins in pristane-induced arthritis. Eur $J$ Immunol 1990, 20:2479-2484

49. Covelli V, Mouton D, di Majo V, Bouthillier Y, Bangrazi C, Mevel JC, Rebessi S, Doria G, Biozzi G: Inheritance of immune responsiveness, life span, and disease incidence in interline crosses of mice selected for high or low multispecific antibody production. J Immunol 1989, 142:1224-1234.

50. Doria G, Biozzi G, Mouton D, Covelli V: Genetic control of immune responsiveness, aging and tumor incidence. Mech Ageing Dev 1997, 96:1-13.

51. Reis MH, Ibanez OM, Cabrera WH, Ribeiro OG, Mouton D, Siqueira M Couderc J: T-helper functions in lines of mice selected for high or low antibody production (Selection III): modulation by anti-CD4+ monoclonal antibody. Immunology 1992, 75:80-85.

52. Prohaszka Z, Fust G: Immunological aspects of heat-shock proteins-the optimum stress of life. Mol Immunol 2004, 41:29-44.

53. Jensen JR, Peters LC, Borrego A, Ribeiro OG, Cabrera WH, Starobinas N, Siqueira M, Ibanez OC, de Franco M: Involvement of antibody production quantitative trait loci in the susceptibility to pristane-induced arthritis in the mouse. Genes Immun 2006, 7:44-50.

54. Nimmerjahn F, Ravetch JV: Fcgamma receptors: old friends and new family members. Immunity 2006, 24:19-28.

55. Oflazoglu E, Swart DA, Anders-Bartholo P, Jessup HK, Norment AM, Lawrence WA, Brasel K, Tocker JE, Horan T, Welcher AA, Fitzpatrick DR: Paradoxical role of programmed death-1 ligand 2 in Th2 immune responses in vitro and in a mouse asthma model in vivo. Eur $\mathrm{J} / \mathrm{mm}$ monol 2004, 34:3326-3336

56. Muto G, Kotani H, Kondo T, Morita R, Tsuruta S, Kobayashi T, Luche H, Fehling HJ, Walsh M, Choi Y, Yoshimura A: TRAF6 Is Essential for Maintenance of Regulatory T Cells That Suppress Th2 Type Autoimmunity. PLoS One 2013, 8:e74639.

57. Bouman A, Schipper M, Heineman MJ, Faas MM: Gender difference in the non-specific and specific immune response in humans. Am J Reprod Immunol 2004, 52:19-26.

58. Singh MP, Rai AK, Singh SM: Gender dimorphism in the progressive in vivo growth of a T cell lymphoma: involvement of cytokines and gonadal hormones. J Reprod Immunol 2005, 65:17-32.

59. Oertelt-Prigione $S$ : The influence of sex and gender on the immune response. Autoimmun Rev 2011, 11:A479-A485.

60. Amadori A, Zamarchi R, de Silvestro G, Forza G, Cavatton G, Danieli GA, Clementi M, Chieco-Bianchi L: Genetic control of the CD4/CD8 T-cell ratio in humans. Nat Med 1995, 1:1279-1283.

61. Michaels RM, Rogers KD: A sex difference in immunologic responsiveness. Pediatrics 1971, 47:120-123.

62. Ishikawa S, Akakura S, Abe M, Terashima K, Chijiiwa K, Nishimura H, Hirose S, Shirai T: A subset of CD4+ T cells expressing early activation antigen CD69 in murine lupus: possible abnormal regulatory role for cytokine imbalance. J Immunol 1998, 161:1267-1273.

63. Struhar D, Harbeck R, Cherniack R: Elastic properties of the excised lungs of NZB/W mice and their correlation with histopathologic changes. Lung 1988, 166:107-112.

64. Sant'Anna OA, Ferreira VC, Reis MH, Gennari M, Ibanez OM, Esteves MB, Mouton D, Biozzi G: Genetic parameters of the polygenic regulation of antibody responsiveness to flagellar and somatic antigens of salmonellae. J Immunogenet 1982, 9:191-205.

65. Patil SA, Katyayani S, Sood A, Kavitha AK, Marimuthu P, Taly AB: Possible significance of anti-heat shock protein (HSP-65) antibodies in autoimmune myasthenia gravis. J Neuroimmunol 2013, 257:107-109.

66. Lightstone L: Lupus nephritis: where are we now? Curr Opin Rheumatol 2010, 22:252-256.

67. van Eden W, Wick G, Albani S, Cohen I: Stress, heat shock proteins, and autoimmunity: how immune responses to heat shock proteins are to be used for the control of chronic inflammatory diseases. Ann N Y Acad Sci 2007, 1113:217-237.

68. Rajaiah R, Moudgil KD: Heat-shock proteins can promote as well as regulate autoimmunity. Autoimmun Rev 2009, 8:388-393.

69. Nishikawa H, Kato T, Tawara I, Saito K, Ikeda H, Kuribayashi K, Allen PM, Schreiber RD, Sakaguchi S, Old LJ, Shiku H: Definition of target antigens for naturally occurring CD4(+) CD25(+) regulatory T cells. J Exp Med 2005, 201:681-686.

70. Paul AG, van Kooten PJ, van Eden W, van der Zee R: Highly autoproliferative $T$ cells specific for $60-\mathrm{kDa}$ heat shock protein produce IL-4/IL-10 and IFN-gamma and are protective in adjuvant arthritis. $\mathrm{J}$ Immunol 2000, 165:7270-7277.

71. Williams GC: Pleiotropy, natural selection, and the evolution of senescence. Evolution 1957, 11:398-411.

72. Zhou L, Yu Y, Chen L, Zhang P, Wu X, Zhang Y, Yang M, Di J, Jiang H, Wang L: Recombinant mycobacterial HSP65 in combination with incomplete Freund's adjuvant induced rat arthritis comparable with that induced by complete Freund's adjuvant. J Immunol Methods 2012, 386:78-84.

73. Giles AR: Guidelines for the use of animals in biomedical research. Thromb Haemost 1987, 58:1078-1084.

doi:10.1186/1742-4933-11-6

Cite this article as: Baldon et al:: Mycobacterium leprae Hsp65 administration reduces the lifespan of aged high antibody producer mice. Immunity \& Ageing 2014 11:6 